Although associated with the American Protein Society, the journal seeks to be international and has a fair representation of articles from both European, non-European and US researchers. The personal touch imparted by a monthly "Recollections" article provides reminiscent reading for more established workers and stimulating reading for younger scientists. In addition, a special section entitled "For the Record" features one-page refereed reports on recent developments. The journal's future looks bright in view of its association with the Protein Society, although I do feel that its news and views on the society caters more for the American than the non-American research worker. But overall the journal will be of use to all researchers interested in protein science and is well deserving of a lasting place among the new journals covering this growing area of research.

J. A. Littlechild is in the Departments of Biological Sciences and Chemistry, University of Exeter, Stocker Road, Exeter EX4 4QD, UK.

\title{
Reading between the vines
}

\section{Robin Goswell}

Journal of Wine Research. Editors Jasper Morris and Tim Unwin. Carfax. 3/yr. US and Canada \$298, Europe £148, elsewhere $£ 177$ (institutional); US and Canada $\$ 107$, Europe $£ 48$, elsewhere £61 (personal).

THIS journal was founded by the Institute of Masters of Wine, an association of professionals working in the UK wine trade who are dedicated to maintaining a high level of expertise, primarily by organizing examinations and conferences. The journal is international and multidisciplinary, publishing the results of recent research on all aspects of viticulture, oenology and the wine trade. It aims to "enhance and encourage scholarly and scientific interdisciplinary research". The editorial and international editorial boards include many distinguished academics and members of the trade. In the two volumes, each of three issues, the editors succeed in obtaining high-quality contributions on a range of topics including practical wine making, viticulture, wine medicine, chemistry, microbiology, geography, geology and history. Papers come from as far afield as Argentina, Australia, Bulgaria, France, Greece, New Zealand, the United Kingdom and the United States.

Of course, most wineproducing countries have their own scientific or technical journals relating specifically to the wine industry. These tend to cover wine chemistry, microbiology, viticulture, practical wine making and economics, but with few exceptions they devote more than 90 per cent of their contents to the national industry and the work of locally based researchers.

A multidisciplinary journal will succeed in its aims only if it earns respect for the quality of the contributions, and if most of its readers and contributors are able to read the majority of the articles with sufficient understanding to gain some stimulus for their own ideas. The quality of the contributions does not seem to be in doubt. The microbiological and chemical articles, the subjects with which I am most familiar, seem to be similar to those appearing in other highly reputable journals. But the highly technical vocabulary used may cause difficul-

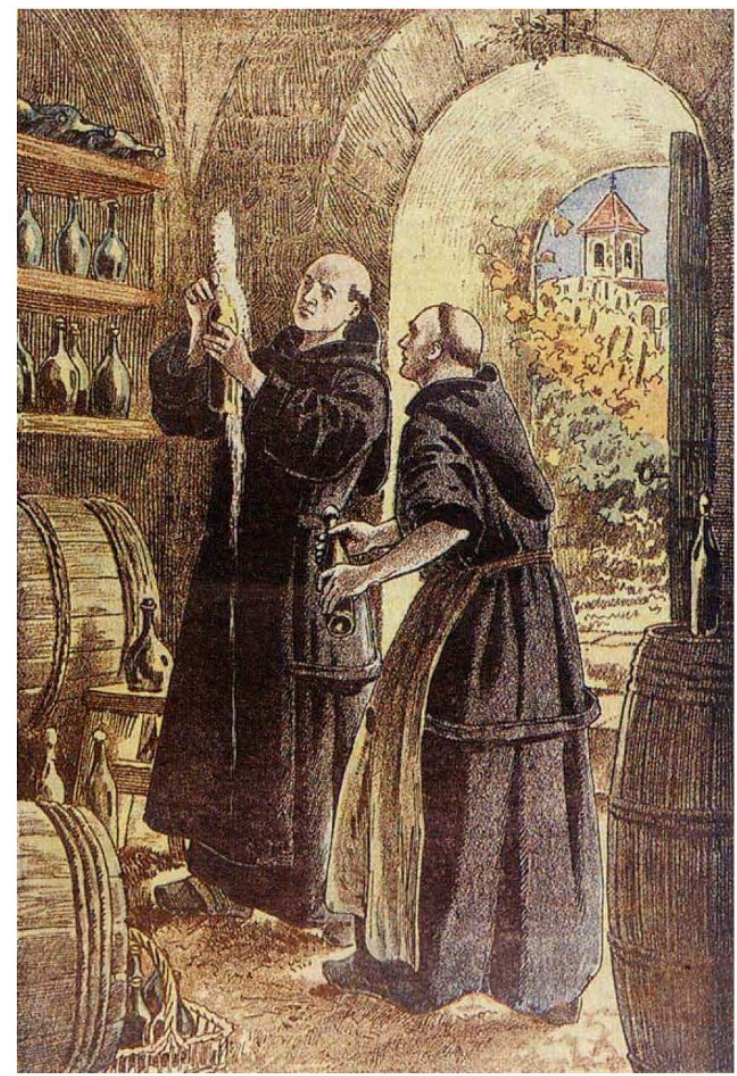

Uncorking a winner - Dom Pérlgnon (1638-1715), a Benedictine monk, discovers the secret of champagne. ty for those trained in other disciplines. For this reason, the editors might be well advised to seek review-type articles as well as reports of original research. Such a policy would certainly not downgrade the scholarly standing of the journal.

Publication of articles seems to be commendably quick, and the presentation of the journal is good. The cost for both individuals and institutions is very much what one would expect under current economic conditions. Altogether, Journal of Wine Research is a worthy enterprise that deserves to succeed.

Robin Goswell is at Harveys of Bristol Ltd, Harvey House, 12 Denmark Street, Bristol $B S 15 D Q$, UK.

\section{Technical triumph}

\section{T. A. Connors}

Toxicology Methods. Editor-in-chief Shayne C. Gad. Raven. 4/yr. US and Canada $\$ 137$, elsewhere $\$ 158$ (institutional); US and Canada $\$ 84$, elsewhere $\$ 97$ (personal).

REVIEWERS of new journals in Nature are offered guidance on what should and should not be included in their review. We should not moan unduly about the ฐ ever increasing number of journals, for example; and we are told that the most important question to be asked about a journal is whether it fills a gap, providing a focus for an emerging discipline or cross-discipline. I believe Toxicology Methods does fill such a gap, although io some people will argue that toxicology has already emerged as a discipline and, to prove it, use words like 'toxicokinetics' instead of the more comfortable 'pharmacokinetics'.

But what is beyond doubt is that toxicology is a cross-disciplinary subject that will continue to grow for the foreseeable future. The introduction of more and more regulations relating to chemicals potentially hazardous to humans, animals, plants and the environment stimulates applied research and the development of tests for risk assessment. These tests often uncover new biological properties of chemicals, which in turn lead to basic studies on mechanisms.

The editor acknowledges that many of the techniques in toxicology have arisen from recent developments in biochemistry and cell and molecular biology, but there is no doubt that increasingly there are techniques and methods invented by toxicologists for the specific needs of toxicologists. Although toxicology jour- 